surface by consequence of change of shape from the level to the convex.

The tunnel, opening out at the butt of the Glacier on to the seabeach, has doubtless been the main outlet for the ground melting, anıl its arched shape may also be deemed significant of the process of convexity adopted by the contraction of the Glacier from side to sille.

The mechanism may be likened to the curling in of the sides of a piece of wood or paper when the flat side is exposed to the fire, ... and it would be all the greater if the other surface were damped, just as the upper surface of the Glacier would be by the rainfall or snowfall of the season. Mr. Melvin's explanation of the formation of the Parallel Roads in Norway valleys may therefore be provisionally proposed to be applied to the phenomena of other Glacier actions, but there are many of these probably that have not convex roofs, nor ground tunnels like the Alaska Glacier. W. J. BLACK.

United Service Club, Edingurgh, February, 1886.

\title{
EDESTUS AND PELECOPTERUS, ETC.
}

Sir,-I observe in your interesting article on the Edestus Davisii, in the January Number of the Geological Magazine, that you refer to the genus Pelecopterus, Cope, as identical with Ptychorlus, Agass.; the pectoral spines representing the former being supposed to belong to the animal whose teeth have given origin to the second name.

My studies of these fishes have led me to entertain a different opinion from the above. Ptychodus, being a shark, is not likely to have a pectoral arch and fin like that of Pelecopterus. Moreover, these pectoral spines have been frequently found associated with the jaws and teeth of the "snout-fishes" of the Kansas Chalk, which have been described under the generic head of Erisichthe, Cope. Several species are known (see Bulletin U.S. Geol. Survey 'Terrs. iii. 1877), and one of them is probably the Xiphias Dixoni of Agassiz, from the Chalk of Sussex, England. These genera cannot be referred to any of the existing orders of fishes, on account of the peculiar structure of the pectoral arch. I have therefore placed them in an especial one, the Actinopteri (see Proceedings Amer. Assoc. Adv. Science, 1877(78), p. 299).

E. D. Cope.

Philadel.phia, Jan. 26, 1886.

NOTE ON THE ABOVE, BY MR. W. DAVIES, F.G.S.

Professor Cope is; I think, mistaken in assigning Xiphias Dixoni to Agassiz. The name first appears in a paper by Dr. Leidy "On Saurocephalus and its Allies," in the Trans. Am. Phil. Soc. vol. xi. p. 91, where the name was given to the prolonged ethmoid bone referred by Sir Philip Egerton to Saurocephalus lanciformis, as then understood.

In that paper Dr. Leidy proves that the teeth assigned by Agassiz to the Saurocephalus of Harlan had no relation to that genus, and he refers the jaws and teeth from the English Chalk to a new genus; under the name of Protosphyrana, Leidy. The "rostral" bones described by Sir Philip Egerton, he contended did not belong to 